O texto seguinte corresponde a um artigo publicado na Revista Galega de Filoloxía, ISSN 1576-2661, 2010, 11: pp.123-149 a que corresponde a seguinte citação

Teixeira, José, 2010, “Categoria nominal e abstracção (ou o porquê das sereias serem mais concretas que o ar)”, in Revista Galega de Filoloxía, № 11/2010, ISSN 1576-2661, Universidade da Corunha (Espanha), pp.123-149.

José Teixeira é Professor de Linguística na Universidade do Minho e investigador do Centro de Estudos Humanísticos da Universidade do Minho 


\title{
Categoria nominal e abstracção (ou o porquê das sereias serem mais concretas que o ar)
}

\begin{abstract}
José Teixeira
ILCH-Universidade do Minho jsteixeira@ilch.uminho.pt

\section{Resumo:}

O presente estudo tem por finalidade tentar demonstrar a não exequibilidade das tentativas de apresentação de critérios dualistas para a classificação tradicional concreto-abstracto na categoria gramatical nome. Depois de sintetizadas as visões tradicionais e respectivos critérios justificativos, apresentam-se os resultados de um inquérito (1403 inquiridos, 22448 respostas) que comprovam que a classificação concreto-abstracto apresenta graus de saliência variável, mas não aleatória, entre os falantes. A partir destes resultados e dentro de uma visão cognitiva do significado como resultante multimodal dos processos perceptivos do ser humano, explana-se um quadro justificativo das relações existentes entre as duas vertentes: mecanismos perceptivos utilizados na conceptualização do real e grau atribuído ao nome na escala concreto-abstracto.
\end{abstract}

Palavras-chave: concreto-abstracto, categoria gramatical nome, léxico, conceptualização, imagens mentais.

Abstract:

This paper claims the impossibility of dualistic criteria to explain satisfactorily traditional nouns classification in terms of concrete-abstract. After summarizing the traditional perspectives and criteria, we present the results of an investigation (1403 people, 22448 answers) showing that the referred classification has variable salience degrees, but not aleatory, among speakers. From these results and within a cognitive vision of the linguistic meaning as a multimodal construction of the human perceptive processes, a scheme is proposed trying to explain the relations between perception and the salience degree of the noun in the concrete-abstract scale.

\section{Key words:}

concrete-abstract; noun as grammar category; lexicon; conceptualization; mental images.

\section{As coisas que custam a entrar na cabeça}

A classificação tradicional da classe gramatical nome tem assentado (como muitas das classificações das chamadas classes de palavras) sobretudo em 


\section{José Teixeira}

critérios de oposição binária. A tradição gramatical racionalista e, nos últimos tempos, muitas das teorias linguísticas, desde o estruturalismo europeu até ao generativismo americano, reforçaram e acentuaram a referida visão dualista e binária. Não é, por isso, de admirar que nas propostas de terminologia linguística mais recentes o nome apareça antinomicamente dividido, para além de outras classificações, entre as classes de "masculino/feminino", “comum/próprio", “animado/não animado", "humano/não humano”, “contável/não contável” e “concreto/abstracto".

Deixando de lado as problemáticas que podem envolver todas as outras, a oposição entre "concreto/abstracto" será, talvez, tida como uma das mais "evidentes” e "naturais", vista como fundada na própria essência das realidades que as palavras designadas por "nomes" ou "substantivos" referem. Daí que seja uma classificação apresentada com a obrigatoriedade de ser ensinada às crianças, normalmente na fase pré-adolescente, e por elas apreendida nos conteúdos relativos ao "funcionamento da língua".

Quem ensina este conteúdo tem experiências suficientes sobre a dificuldade de classificar como concreto ou abstracto os nomes ou substantivos: os que aparecem como exemplos, ainda vá; mas quando se começa a querer saber fora das listagens dos exemplos que os manuais trazem a coisa fica, por vezes, bastante complicada.

O pequeno episódio recolhido num sítio da internet, intitulado "Quando a gente é criança, tem algumas coisas que não entram na cabeça de jeito nenhum” pode ilustrar muitas situações semelhantes:

Eu me lembro, por exemplo, que, por mais que a professora se esforçasse e desse exemplos e explicasse, eu não conseguia apreender direito a diferença entre substantivos abstratos e concretos. E ela dizia: "Abstrato é aquilo que a gente não pode tocar"; e eu retrucava: "Então vento é abstrato"; e ela: "Não, porque vento a gente sente"; e eu, mais uma vez, com a fantástica sensibilidade de criança: "Então alegria é concreto, porque a gente sente também". É, criança não está muito afeita a essas diferenças entre concretos e abstratos... (Christian David Soares Bittencourt, in http://xacute.sites.uol.com.br/art_espiritualidade.html em 6/10/2009)

\section{Os critérios tradicionalmente apresentados}

\subsection{A visão binária}

A oposição binária entre nomes concretos e abstractos é, como já se disse, a que tradicionalmente se apresenta como estruturadora da classificação. 


\section{José Teixeira}

Profundamente enraizada nas concepções gramaticais de pendor logicista é igualmente legitimada pelos pressupostos da separação nítida entre significado e referente e matéria/espírito, sendo este entendido sobretudo numa visão cartesiana, como algo separado do corpo e das suas actividades perceptivocognitivas.

Esta base cartesiana corpo-alma de entendimento das interacções cognição humana-referencialidade linguística procura evidenciar a oposição concretoabstracto através de critérios que apareçam como lógicos, evidentes.

$\mathrm{Na}$ verdade, não é fácil perceber, para além dos exemplos tipificados, quando é que um nome (ou substantivo, na designação menos recente) é “concreto" ou "abstracto". É que o axioma de base de que se parte (que se pressupõe nem precisar de ser discutido) é que a coisa não tem meios-termos: ou é cem por cento concreto ou cem por cento abstracto. As "coisas" (e por isso as palavras que as referem) ou são concretas ou não!

Valerá a pena, talvez, verificar os critérios tradicionalmente apresentados para fazerem "entrar na cabeça" a separação do "concreto" do "abstracto" porque tais critérios são sintomaticamente reveladores da complexidade desta oposição e dos equívocos que têm contaminado a análise linguística tradicional.

\subsubsection{Os cinco sentidos}

Pode dizer-se que os critérios mais referidos para estabelecer a oposição “concreto/abstracto" são de ordem cognitiva, na medida em que apelam para a forma como percepcionamos a realidade:

[o nome concreto] Designa seres ou sensações que podemos perceber pelos sentidos.

cais, telhado, carta

[o nome abstracto] Designa ideias, sentimentos ou sensações que não podemos perceber pelos sentidos. ${ }^{1}$

A questão aqui, como se vê, é a possibilidade de os "seres ou sensações" poderem ou não ser percebidas "pelos sentidos". Trata-se, portanto, de uma questão perceptiva. Mas a que sentidos se refere? Deduz-se que aos tradicionais “cinco sentidos” (visão, audição, odor, tacto e gosto). Parecerá, nestes moldes, que medo será nome concreto porque é uma sensação que "podemos perceber pelos sentidos”. Não. Medo é apresentado como um dos melhores exemplos para os nomes abstractos, juntamente com ânimo e amabilidade! E se ar, pela definição, será concreto, sereia deverá ser abstracto, porque, ao que se saiba, as sereias não podem ser percebidas pelos (cinco) sentidos...

\footnotetext{
${ }^{1}$ Silva, Ana Maria, Fontes, Maria José, Castro, Rogério de, 2002: 102.
} 


\subsubsection{O mundo físico}

Outro critério separador já não usa os processos da percepção, mas antes as características da realidade em si mesma e sobre a qual se volta a percepção: físico:

Os nomes concretos designam pessoas, animais ou coisas pertencentes ao mundo

O Rui esteve na praia

A tia trouxe-lhe um cesto de cerejas

São nomes concretos: Rui, Isabel, pai, tia, gato, abelha, praia, cesto, cerejas, cerejeira, árvore, casa, pedra.

Os nomes abstractos designam acções, qualidades ou estados:

Já sabemos que a conversa esteve muito animada

A Torre de Belém é um monumento de grande beleza

São nomes abstractos: conversa, vigor, esforço, beleza, heroísmo, franqueza, frio, alegria, inteligência. ${ }^{2}$

Aqui sereia também seria palavra abstracta já que não pertence ao mundo físico (supõe-se...). No entanto, pelos exemplos dados, também se pode ficar confuso sobre o que é “o mundo físico”, já que conversas e frio são consideradas palavras abstractas, designando, portanto, realidades que nele não se incluem!

\subsubsection{O mundo mental}

Uma mudança substancial nos critérios para a classificação “concreto/abstracto" parece ocorrer quando se deixa de considerar que o mundo que a língua refere não é apenas o mundo físico de referencialidade objectual comprovável através dos cinco sentidos.

A definição de "nome concreto" apresentada a seguir parece fundada numa visão saussureana de significado como entidade conceptual, um conceito mental e linguisticamente estruturado independentemente da sua existência ou não no mundo físico:

Os nomes concretos nomeiam pessoas, coisas e animais que realmente existem ou se acredita que existam: Luís, Rosa, Porto, Tejo, sala, gato, Deus, anjo.

Os nomes abstractos nomeiam tudo o que representa apenas ideias do nosso pensamento: trabalho, preguiça, bondade, maldade, frio, calor, alegria, tristeza, saudade, esperança, coragem, saúde, força, fraqueza. ${ }^{3}$

Ao não apelar para a existência real da entidade nominalizada ("existem ou se acredita que existam" como Deus, anjo) esta perspectiva assenta apenas na realidade conceptual, ou seja, na existência de um conceito sobre uma entidade

\footnotetext{
${ }^{2}$ Pinto, José Manuel de Castro, Lopes, Maria do Céu Vieira, 2002: 115.

${ }^{3}$ S/ Autor, 2004: 86.
} 


\section{José Teixeira}

mentalmente construída. Se essa entidade conceptual tem um referente no mundo físico ou não, será indiferente para o carácter concreto do nome. E nesta perspectiva, sereia que tinha que ser inserida nos abstractos pelas classificações dos "cinco sentidos" e do "mundo físico" passará para o grupo dos concretos.

No entanto, a aparente coerência é destroçada pelos critérios definidores do nome abstracto: "Os nomes abstractos nomeiam tudo o que representa apenas ideias do nosso pensamento". Então Deus e anjo não foram considerados concretos por "representarem ideias do nosso pensamento" independentemente da sua existência física ou não? Afinal, a sereia não está segura nos concretos? Depende se acharmos que elas existem ou não? E frio e calor são nomes abstractos porque "representa(m) apenas ideias do nosso pensamento"?

\subsubsection{A autonomia}

Um critério que aparece com mais frequência na gramática brasileira do que na portuguesa é o da autonomia: um nome é concreto se a realidade a que se refere não depender de ninguém, se for autónoma:

[os nomes concretos] São aqueles que subsistem por si só, cuja existência não depende de outro ser. Vejamos o substantivo mesa. Para o objeto existir, precisou, sem dúvida, do artesão. Concluída a obra, o objeto mesa tem existência própria, sem depender de qualquer outro ser para continuar existindo.

São concretos também os substantivos imaginários, aqueles que o povo dá uma forma: lobisomem, sereia, fada. Como se vê, a classificação concreto nada tem a ver com a existência real do ser, mas com a subsistência, ou seja, tudo o que tem ou crê ter existência real. É fácil perceber que todo substantivo concreto é suscetível de ser desenhado, já que é possível lhe dar uma forma: árvore, céu, estrela, mula-semcabeça, inferno, saci...

São [concretos] os nomes de pessoas, animais, lugares coisas: poeta, professor, lobo, ovelha, Paris, América, ouro, bolsa.

[os nomes abstractos] São aqueles que não subsistem por si só, cuja existência depende de outro ser. Assim, o substantivo saudade só existe no indivíduo, impossível separá-lo do pensamento. Desta maneira, os abstractos nomeiam idéias (ações, qualidades e estados):

É fácil perceber que nenhum substantivo abstracto pode ser desenhado, já que não tem uma forma, só existindo no indivíduo: civismo, justiça, tristeza, elegância, fascinação, ternura, inquietação, ódio, raiva, obsessão, ilusão, amizade, respeito.. ${ }^{4}$

Não se percebe muito bem, contudo, como funciona este critério de autonomia: os "substantivos imaginários, aqueles que o povo dá uma forma:

\footnotetext{
${ }^{4}$ Miguel, Jorge, 1989: 67.
} 


\section{José Teixeira}

lobisomem, sereia, fada" são dados como exemplos de concretos. No entanto, eles não têm existência só por si; por definição dependem da existência de quem os concebe, ou melhor, concebe as realidades que eles designam, já que se não houver quem as conceba eles não existem. A relação mente humana-entidade imaginária é diferente da relação artesão-mesa, para usar os exemplos apresentados. Se "concluída a obra, o objecto mesa tem existência própria, sem depender de qualquer outro ser para continuar existindo", o mesmo não acontece com a entidade imaginária. Ela só existe no imaginário do imaginador, não tem existência real para além dele. Por conseguinte o critério da autonomia não funciona nestes casos “imaginários” que vão desde a alma (real ou não, autónoma ou não) e Deus a toda a mitologia universal, desde o Pai-Natal às fadas, duendes e sereias.

Por outro lado, embora se diga que "a classificação concreto nada tem a ver com a existência real do ser”, na verdade o critério da fisicidade continua a ser fundamental, já que o argumento central para a verificabilidade de ser concreto ou abstracto é ... poder ser desenhado ("É fácil perceber que todo substantivo concreto é susceptível de ser desenhado [...] É fácil perceber que nenhum substantivo abstracto pode ser desenhado").

\subsubsection{As listagens}

Como se constata pelo apresentado, não é fácil estabelecer um critério que seja univocamente funcional na oposição binária entre concreto-abstracto. Quer se escolha o tipo de percepção, quer se escolha a obrigatoriedade de existência física ou apenas a existência "imaginária” ou ainda o critério da autonomia, resulta sempre uma classificação muito difícil de aplicar fora dos exemplos canónicos (e mesmo nesses, pensando bem, as coisas são mais complexas do que o que parecem...). Daí que algumas propostas acabem por não apresentar critérios de separação, mas listagens de (hipotéticas) subclasses de palavras e respectivos exemplos:

[concretos] São os substantivos que designam nomes de coisas, animais, pessoas e instituições: terra, arvore, pinheiro, Setúbal, mulher, Maria, bebé, cozinha, panela, clero.

[abstractos] São os substantivos que designam acções, qualidades, estados, noções: altura, amargura, bondade, brilho, caridade, claridade, doença, estupidez, força, limpeza, sabedoria, subtileza. ${ }^{5}$

\subsection{Visões mais ou menos gradativas}

É facilmente constatável que a perspectiva dualista encontra grandes problemas no tratamento da oposição concreto-abstracto. Não é de admirar,

\footnotetext{
${ }^{5}$ Borregana, António Afonso, 1998: 118.
} 


\section{José Teixeira}

portanto, que as análises menos simplistas e mais fundamentadas prefiram uma perspectiva graduável, vendo a oposição concreto-abstracto como um continuum gradativo entre dois pontos de referência.

Os diferentes tipos de nomes [...] mostram a necessidade de conceber a oposição tradicional concreto/abstracto como uma grandeza escalar, assumindo os vários tipos de nominais diferentes valores (posições) na escala concreto - abstracto. ${ }^{6}$

No entanto, e embora se diga o contrário, bem vistas as coisas, a perspectiva de fundo continua a ser dual:

Os nominais em itálico (urso, verdade) remetem, ao nível do seu próprio conteúdo lexical, para objectos de diferentes tipos. Assim, numa situação concreta de comunicação, o nominal (urso) designa um objecto físico, animado, localizado (ou, pelo menos, localizável) espácio-temporalmente, com propriedades directamente observáveis. Por sua vez, verdade designa um objecto não observável directamente, não animado, não localizável espácio-temporalmente. Pode, portanto, considerar-se nominais como verdade de tipo superior a nominais como urso: reportando-nos à oposição tradicional concreto/abstracto, atribuiríamos aos últimos a propriedade concreto e aos primeiros a propriedade de abstracto. ${ }^{7}$

Defende-se nesta visão, apesar da dualidade de fundo, a admissão de uma escala de inferioridade-superioridade correspondente ao grau de abstracção. No entanto, os critérios para tal diferenciação não são assumidamente os critérios linguístico-perceptivos, mas critérios baseados em hipotéticas essências das próprias referências nominais. Na realidade, falar em "propriedades perceptuais directamente observáveis” parece supor que estas propriedades estão nos "objectos" e não na actividade cognitiva que envolve objecto-sujeito linguístico. Além disso, refere-se o que é "directamente observável” como se a "observabilidade directa" fosse uma propriedade dos objectos e realizada pelos sujeitos com os mesmos instrumentos e parâmetros, não havendo hierarquias perceptivas.

Relativamente aos grupos (ou sintagmas) nominais complexos, defende, esta visão, uma relação entre complexidade e abstracção:

Um processo de construção de nominais de tipo superior é o que consiste em construir sintagmas nominais complexos como ilustrados em (3):

(3) (a) A gulodice desse urso salta à vista.

(3) (b) A violência do rapto arrepiou os transeuntes.

\footnotetext{
${ }^{6}$ Mateus, M Melena, 2003: 211.

${ }^{7}$ Mateus, $\mathrm{M}^{\mathrm{a}}$ Helena, 2003: 212.
} 
Os SNs em itálico em (3a) e (3b) são de tipo superior aos nomes urso (1a) e rapto (2b). Neste caso, considera-se como objecto nomeável uma propriedade de um dado individual (gulodice, urso, em (3a)) ou uma propriedade de uma situação (violência, rapto em (3b)). Assim, na escala concreto-abstracto, gulodice desse urso é mais abstracto do que urso, e violência do rapto mais abstracto do que rapto. ${ }^{8}$

Não se negando que relações de dependência estrutural do género das apresentadas exponenciam o grau de abstracção de um nome, deve, no entanto, notar-se que não é apenas a estrutura em si, o esquema estrutural de dependência, que coloca o nome num determinado grau de abstracção. Ou seja, como se diz "na escala concreto-abstracto, gulodice desse urso é mais abstracto do que urso"; mas isto não acontece por causa da estrutura, só por si, mas porque gulodice é mais abstracto do que urso.

Senão vejamos, mantendo a mesma estrutura: se fosse os dentes desse urso, este grupo nominal era mais abstracto que urso? Já no outro exemplo apresentado, não é pacífico que violência do rapto seja mais abstracto que rapto.

E noutras dependências estruturais do género: murro de raiva é mais abstracto que raiva, beijo de amor mais abstracto que amor, caminhos da felicidade mais abstracto do que felicidade?

Posição muito semelhante, que defende a gradatividade de uma escala, aparece na célebre TLEBS (Terminologia Linguística para os Ensinos Básico e Secundário): "não existe uma oposição entre concreto / abstracto, mas diferentes valores numa escala concreto-abstacto". Mas apesar desta visão gradativa da questão, o substrato teórico em que assenta continua a ser o da dualidade, enformada pela contraposição cartesiana entre matéria-imatéria:

\footnotetext{
Um nome concreto aplica-se a um objecto ou entidade tipicamente tangível (i), enquanto um nome abstracto se aplica a realidades imateriais (ii). [...]

(i) porta, edifício, água, farinha, homem...

(ii) amor, violência, educação, segurança, agradecimento. ${ }^{10}$
}

Mas a questão persiste: que critérios devem ser elencados para verificar a "tangibilidade" dos objectos nomeados linguisticamente? O que é que é ser uma "realidade imaterial”? Há discrição ou continuidade entre as "realidades tangíveis” e as "realidades imateriais”?

\footnotetext{
${ }^{8}$ Mateus, M ${ }^{\mathrm{a}}$ Helena 2003: 212.

${ }^{9}$ Duarte, Inês, CD-ROM.

${ }^{10}$ Duarte, Inês, CD-ROM.
} 


\section{O concreto na cognição}

A questão está precisamente aqui: a “tangibilidade” que dá o carácter concreto aos nomes não é uma realidade unívoca e uniforme, porque não é uma característica dos objectos, mas sim a resultante das actividades de apreensão cognitiva do sujeito. Valerá, talvez, a pena consciencializarmo-nos dos factos que a neurociência apresenta:

Quando o leitor ou eu olhamos para um objecto exterior a nós, formamos imagens comparáveis nos nossos respectivos cérebros. Temos a certeza que assim é, porque tanto o leitor como eu conseguimos descrever esse objecto de maneira muito semelhante, mesmo nos mais ínfimos detalhes. Porém, isso não significa que a imagem que nós vemos seja a cópia do objecto exterior a nós. Como o objecto é, em termos absolutos, não sabemos nem nunca viremos a saber. A imagem que vemos baseia-se em modificações que ocorrem no nosso organismo -incluindo a parte do organismo chamado cérebro- quando a estrutura física do objecto interage com o corpo. Os dispositivos sinalizadores localizados em todas as estruturas do nosso corpo -na pele, nos músculos, na retina, etc. - ajudam a construir padrões neurais que cartografam a interacção do organismo com o objecto. [...] Não existe nenhuma imagem de um objecto a ser transferida do objecto para a retina e da retina para o cérebro. Existe, sim, um conjunto de correspondências entre as características físicas do objecto e os modos de reacção do organismo segundo os quais uma imagem, internamente gerada, acaba por ser construída. Como tanto o leitor como eu somos parecidos do ponto de vista biológico, acabamos por construir uma imagem parecida de uma mesma coisa, e podemos por isso aceitar, sem protesto, a ideia convencional de que formámos a imagem real de uma coisa específica. Mas, no fundo, não formámos. (Damásio 1999 (2004): 365-366)

Segue-se, portanto, que as imagens mentais resultantes das actividades cognitivas são intrinsecamente multimodais e multiprocessuais. Elas não são uma "parte" que emana das coisas, mas construções mentais que elaboramos por causa das modificações que o nosso sistema perceptivo sofre em cada acto de percepção. Por isso, essas imagens construídas não são discretas, oposições dicotómicas, passíveis de serem reduzidas a dois pólos extremos -ou concretas, ou abstractas.

Daí que ao admitir-se a gradatividade da relação nominal concreto-abstracto terá que se supor obrigatoriamente que

1. esta gradatividade (concreto-abstrato) resulta do processo cognitivo com que o falante processa e organiza as suas cognições em conhecimento linguístico; 
2. essas cognições envolvem vários instrumentos, várias formas e esquemas perceptivos;

3. os instrumentos perceptivos não têm todos o mesmo peso na construção das percepções, tendo este facto consequências na hierarquização das mesmas;

4. a resultante perceptiva que enformará o escalonamento do nome na escala do concreto-abstrato não é uma característica intrínseca das coisas, mas resultante dos processos e actividades de cognição obrigatoriamente implicados.

Nunca se poderá, naturalmente, supor que os processos descritos são puramente de carácter individual, já que se passam "no interior” do indivíduo. Seria um absurdo: como é que eles "coincidem” tão bem com os dos outros indivíduos falantes da mesma língua? Obviamente que todos estes processos são constantemente enformados, guiados, pelas categorizações e esquemas linguístico-cognitivos que o indivíduo, porque falante da língua, não pode desligar enquanto processa a realidade e que lhe indiciam o modo como deve organizar linguisticamente as cognições que vai experienciando.

\section{O léxico e o significado corporizado}

Esta questão da dimensão do carácter concreto ou abstracto torna-se, assim, particularmente interessante para mostrar não apenas a profunda relação existente entre o designado "conhecimento enciclopédico" e o "conhecimento linguístico", mas igualmente como, na verdade, o significado é corporizado. Por outras palavras, o "sentido" linguístico é inseparável e decorre da forma como "sentimos" a realidade.

As línguas são essencialmente o resultado de uma interacção cognitiva e vivencial entre os seres humanos e o meio em que estão inseridos, incluindo neste meio a contextualização ecológica e cultural. Por isso, as línguas significam, acima de tudo, o que experienciámos e vamos experienciando. Não é só a mente que aprende a verbalizar significados; o corpo também está presente em todo o processo. A tradição positivista e racionalista das ciências, alicerçada numa posição marcadamente anti-subjectivista, esqueceu-se bastante desde aspecto. Como cada vez mais mostram as ciências neuro-fisiológicas, corpo e mente são as duas faces da uma mesma moeda. Por isso, se pode dizer que, semanticamente, todo o sentido linguístico teve de ser sentido, cognitivamente experienciado, pelo homem. Por outras palavras, o “signo da língua” é apenas uma abstracção teórica 


\section{José Teixeira}

do sentido que realmente as línguas comportam. E assim, porque é uma ficção abstracta, nenhum falante tem acesso ao significado da língua, mas todos usam e experimentam o sentido.

A Linguística Cognitiva acentua a complementaridade entre a nossa realidade física e perceptiva, por um lado, e a configuração linguística, por outro. De certo modo, tende a questionar o axioma da não arbitrariedade do signo, pelo menos relativamente aos mecanismos psico-fisiológicos que secanarizam o mundo na produção do significado linguístico. O significado está intrinsecamente dependente do modo como percepcionamos e interagimos com a realidade. Pode não a reflectir em espelho, mas pelo menos procura encarnar, modelizar, esquematizar o conhecimento e todo o universo de crenças que vamos construindo sobre essa realidade que vivenciamos.

Este processo não é feito através de mecanismos lógicos, abstractos, independentes da realidade, mas através de configurações corporizadas e cognitivamente dependentes; sentidas, no fim de contas. Assim, se se encarar a língua como uma estrutura dependente da cognição humana, respectivas crenças e experiências físico-perceptivas, então os sentidos, e depois os significados, não são totalmente arbitrários, mas profundamente dependentes da relação cognitiva existente entre o falante e o mundo (físico ou mentalmente construído) que a língua refere. ${ }^{11}$

Lakoff designa esta síntese entre os mecanismos cognitivos e o processamento semântico das e nas línguas por embodied meaning: o significado é corporizado, percepcionado corporalmente, no sentido de "organizado através das nossas experiências corporais e sensitivas". Na mesma linha em que se inscreve António Damásio ${ }^{12}$, a construção do significado implica mecanismos simultaneamente físicos e cognitivos:

They all added up to the idea that meaning was embodied, that you could not have disembodied meaning, disembodied reason. That entailed that you could not use the kind of mathematics that Chomsky had used in characterizing grammar in order to characterize semantics. The reason was, as we had first shown in generative semantics, that semantics had an effect on grammar, and we tried to use combinatorial mathematics to characterize logical form. We thought that the use of formal grammars plus model theory would enable us to do syntax and semantics and the model theoretic interpretation.

However, if meaning is embodied, and the mechanisms include not just arbitrary symbols that could be interpreted in terms of the world but things like basic level categories, mental images, image schemas, metaphors, and so on, then there simply would be no way to use this kind of mathematics to explain syntax and semantics. (Lakoff 1995:120-121)

\footnotetext{
${ }^{11}$ Ver Teixeira, 2001: 80-130.

${ }^{12}$ Ver Damásio, 1995.
} 
O conceito de embodied meaning pressupõe uma visão do significado um pouco divergente do tratamento lógico-matemático que as semânticas de natureza formal privilegiaram. A clássica separação entre o "sentir" corpóreo e o "saber" linguístico-mental (na tradição cartesiana, dita científica porque não subjectiva), prolonga a separação tida como inquestionável entre o corpo (o sentir) e o espírito (o conhecer). Este “erro de Descartes”, nas palavras de António Damásio (1995), também nas ciências da linguagem foi responsável pela tentativa de se conceber o significado e o conhecimento humano como duas realidades quase independentes de todo o ser físico e de toda a experiência sensitiva do homem que (se) constrói (n)uma determinada língua:

There have been two generations of cognitive science. In the first generation, it was assumed that mental representation was done in the way suggested by logicians: that there was either a logical form or an image representation made up of symbols and structures of symbols, and that these symbols represented things in the external world or categories in the external world. They were internal representations of some external reality. This was part of the "disembodied mind" view-the view that you could characterize a mind in purely abstract terms using abstract symbols and that this had nothing to do with the body, with perceptual mechanisms, and so on. (Lakoff1995:122)

Ora aceitando-se, então, que é com o corpo que sentimos, que é com o corpo que apreendemos as realidades que depois configuramos linguisticamente, ter-se-á que aceitar também que os nossos processos de apreensão sensitiva são, obrigatoriamente, a fonte para qualquer processo de organização perceptiva, como acontece com a conceptualização que enforma o léxico mental e, no que aqui nos interessa, a vertente da escala concreto-abstracto.

\section{Concreto-abstracto e gradação perceptiva}

\subsection{A realidade e as percepções sobre ela}

Que a dimensão concreto-abstracto não se estrutura num enquadramento puramente dual prova-o o facto de ser, em muitos casos, extremamente difícil para o falante dizer em qual dos dois grupos determinado nome deve ser inserido (ver atrás 1. "As coisas que custam a entrar na cabeça”). Há termos mais ou menos globalmente entendidos como concretos ou abstractos, mas há um grande número deles perante os quais os falantes ora os inserem num grupo, ora noutro, com graus de incerteza razoavelmente constantes. Esses graus de incerteza, visíveis em 


\section{José Teixeira}

inquéritos a número suficiente de falantes, mostram ser a oposição concretoabstracto nitidamente construída em termos de uma escala contínua.

Para comprovar estes pressupostos, apresentam-se dados de um inquérito realizado no ano de 2005. Foram 1403 os inquiridos, num total de 22448 respostas. Os inquéritos foram feitos em universo escolar a alunos do ensino secundário (com idades na franja 11-18 anos). Entregava-se ao inquirido uma folha de papel com uma tabela com uma listagem de 16 nomes (Porta, Alegria, Dia, Tristeza, Cadeira, Dor, Colheita, Viagem, Sereia, Luz, Árvore, Ar, Velhice, Pomar, Felicidade, Doença) e espaço para assinalarem se consideravam o nome concreto ou abstracto (ver Anexos, onde se encontram, igualmente, os resultados por nível etário, resultados globais e respectivas tabelas).

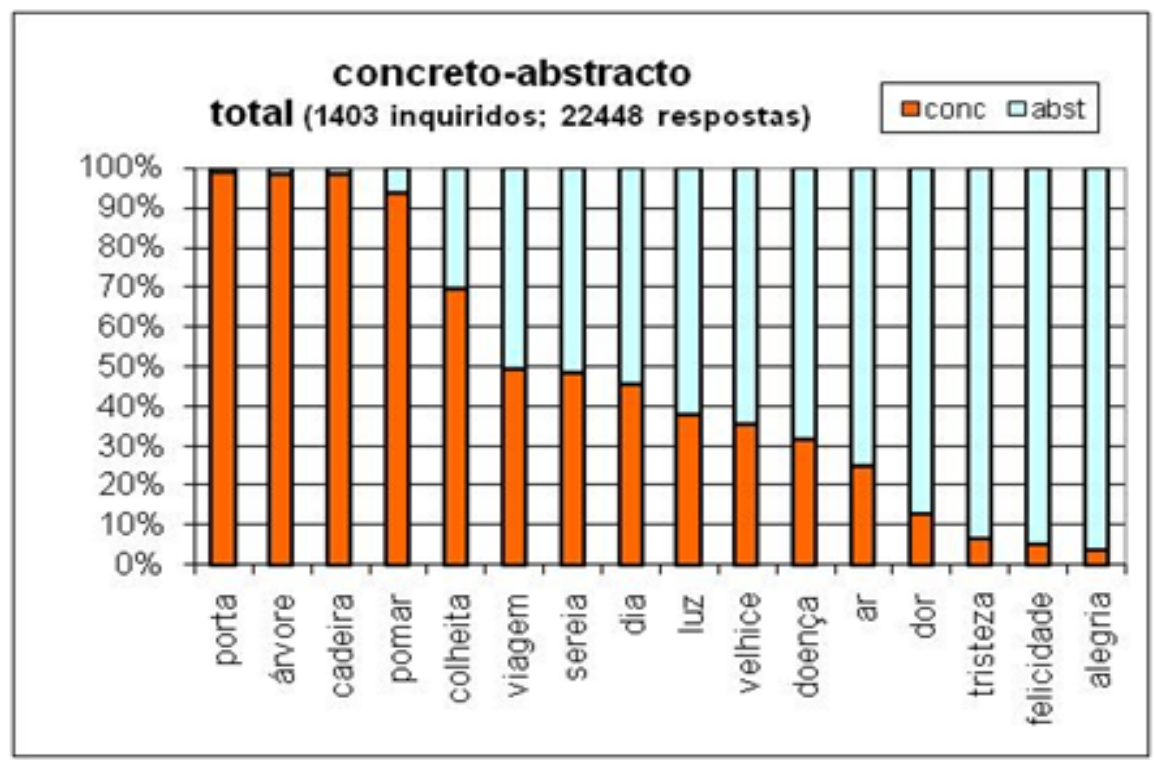

Figura 1

A Figura apresenta os resultados globais. Sem grandes surpresas, desde um grupo quase unanimemente considerado "concreto" até ao extremo dos quase unanimemente "abstractos" e outros que se inserem em percentagens intermédias. Os dados parciais (ver Anexos) confirmam a sistematicidade e não aleatoriedade dos dados totais: em seis grupos etários diferentes há, globalmente, coincidência de resultados, verificando-se um grupo de "muito concretos" (porta, cadeira, árvore, pomar), um de "muito abstractos" (dor, tristeza, felicidade, alegria) e o grupo dos restantes com valores intermédios na escala. 


\section{José Teixeira}

\subsubsection{A percepção directa}

O que é que leva os falantes a mentalmente atribuírem um determinado grau de "concretude" 13 a um item lexical?

É intuitivo que o grau de intensidade das percepções estará directamente relacionado com a dimensão “concreto” atribuída aos nomes. As expressões que tradicionalmente referem a "tangibilidade”, o serem "coisas reais”, "percebidas pelos sentidos, "observáveis", "sentidas" e outras do género pretendem indicar precisamente o grau elevado de percepção presente na atribuição da característica referida -o ser nome concreto.

Não há, no entanto, apenas uma forma de percepção directa, mas várias, as quais dependem, por um lado da variedade dos sentidos estimulados no indivíduo e por outro da própria constituição da realidade a percepcionar.

Como facilmente se percebe, é ao sentido da visão que nós atribuímos a primazia na percepção da realidade. O peso deste sentido na atribuição do carácter "concreto" é, nítida e incomparavelmente, superior ao de todos os outros. Por isso é que há classificações que definem os nomes concretos como aqueles que podem ser desenhados:

\footnotetext{
É fácil perceber que todo substantivo concreto é suscetível de ser desenhado, já que é possível lhe dar uma forma: [...]

É fácil perceber que nenhum substantivo abstracto pode ser desenhado, já que não tem uma forma, só existindo no indivíduo ${ }^{14}$.
}

Esta faceta de representatividade visual é mais básica quando referencia um objecto singular por oposição a realidades colectivas: homem é nome mais concreto do que multidão, árvore mais concreto que pomar. Por isso, nos resultados dos inquéritos, os três nomes que referem objectos visíveis e individuais (porta, árvore, cadeira) aparecerem identificados como concretos por praticamente todos os inquiridos (ver Figura 1 e Anexos). Já pomar, entidade

\footnotetext{
${ }^{13}$ Com o termo "concretude” pretende-se indicar a característica daquilo que é concreto. Não se relaciona com “concretismo” ou “concretizar”, já que estes termos indicam a concretização de algo tido originalmente como mais abstracto (“concretizar uma ideia”). Aqui trata-se de referir uma característica atribuível às entidades que os nome designam, característica essa que permite que para o falante o nome seja mais ou menos concreto. Embora o termo não apareça no Dicionário da Língua Portuguesa Contemporânea da Academia das Ciências de Lisboa (2001), encontra-se no Dicionário Houaiss da Língua Portuguesa (2001).

${ }^{14}$ Miguel, Jorge, 1989: 67.
} 


\section{José Teixeira}

colectiva, embora esmagadoramente considerado nome concreto, fica sempre, em todos os seis grupos etários (e note-se a constância), em quarto lugar, depois dos assinalados porta, árvore, cadeira.

A não visibilidade faz uma demarcação vincada entre os directamente experienciáveis. Ser "apreendido pelos sentidos”, ao contrário do que algumas classificações expressam, não é condição suficiente para ser considerado altamente concreto, se nesses sentidos não se incluir a visão.

Assim, este grupo perceptivo (os directamente experienciáveis mas sem a visão) pode, pensamos, ser subdividido em dois: quando a percepção sem visão envolve várias experienciações directas (sons, sentido térmico, odores) ou quando envolve apenas percepções de nível periférico que, embora físicas, o são em grau relativamente pouco acentuado, como acontece com a percepção do ar ou da luz. Aquele é de difícil percepção e a luz é dificilmente separável dos objectos que a emanam.

Podíamos, assim, considerar um primeiro quadro justificativo da “concretude” baseada na percepção directa:

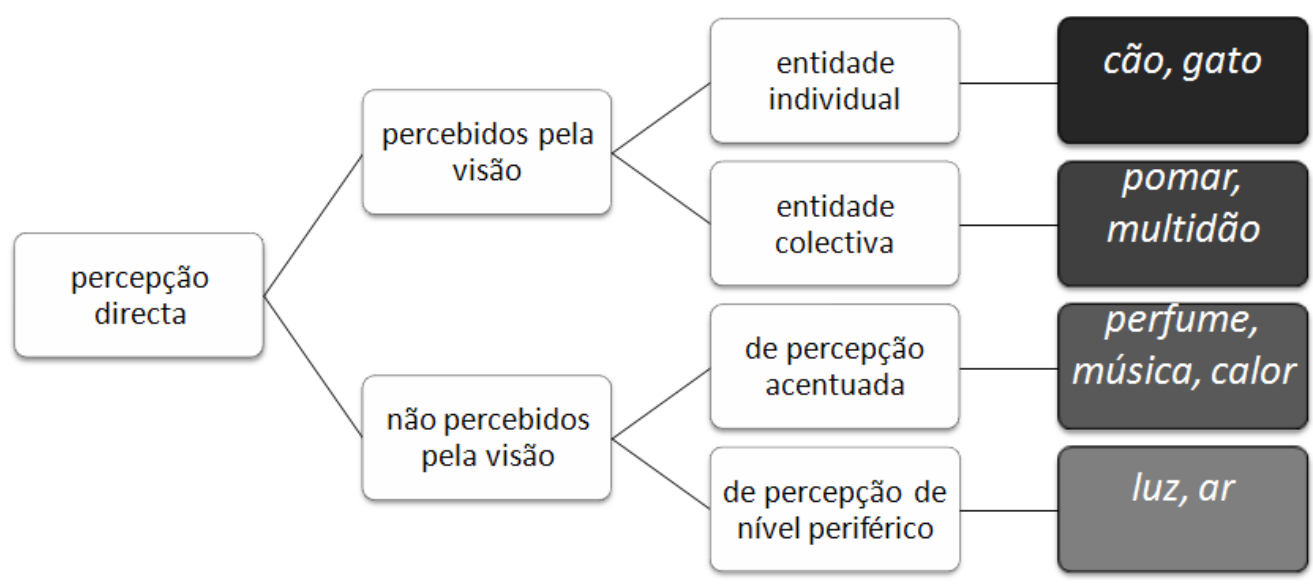

Figura 2

\subsubsection{A percepção indirecta}

Falar-se em percepção directa implica, naturalmente, aceitar que muitas conceptualizações se alicerçam em percepções indirectas. São os casos dos processos (como viagem, colheita, doença, velhice, morte), construídos 


\section{José Teixeira}

mentalmente por um conjunto de dados estruturados sobre várias apreensões sensoriais já experienciadas (as várias coisas que uma realidade implica, que nós já sentimos, experienciámos, vimos ou supomos).

Uma outra vertente de conceptualizações construídas por percepção indirecta é a dos estados. Não difere muito da dos processos. Há entidades que ora podem ser construídas como processos, ora como estados, como acontece com doença ou velhice, por exemplo. O facto de os falantes hesitarem muito para atribuir o carácter concreto ou abstracto a entidades deste tipo prende-se, precisamente, com este facto: elas podem ser perspectivadas enquanto processos, conjuntos de actividades (numa doença alguém tem dores, sente-se mal, experimenta sensações desagradáveis, ...) ou enquanto um estado (“estar doente”, pode ser visto como uma característica como “estar triste” ou “estar infeliz”).

Uma terceira vertente, menos baseada na percepção sensorial directa, construída a partir de conceptualizações tidas como reais é constituída pelas chamadas "realidades dos universos de crença". Os nomes de entidades como anjos, deuses, fadas, sereias, são, por norma, postos, pelas classificações tradicionais bipolares, do lado dos nomes concretos.

Aparentemente, esta classificação foge à "lógica" da antinomia concretoabstracto, se se supuser que esta se baseia no que existe realmente e pode ser experimentado pelos sentidos. Mas não é bem assim. Os sentidos são apenas a fonte para a constituição das conceptualizações e é nestas que é enformada a "concretude" ou abstracção dos termos que linguisticamente as representam. Para além disso, as entidades dos universos de crença têm um grau de crença existencial muito variável entre os falantes. Se o critério fosse a existência real, Deus e anjos não encontrariam consenso sobre a sua realidade (e carácter concreto, portanto) entre os falantes.

Há, ainda, um outro factor que interfere com a dimensão "existência real" que, como se disse, não é critério para se ser concreto. Esse factor, por paradoxal que pareça, é a visibilidade. É que as realidades (possivelmente) não existentes podem ser visíveis, através de representações icónicas. Pode-se dar visibilidade às fadas, aos anjos, a Deus, ao Pai-Natal e, assim, elas passam a poderem ser "vistas". Lembre-se o já atrás citado, para alguns gramáticos, critério de "poder ser desenhado" para um nome poder ser considerado concreto.

E é por isso que as sereias são sempre mais concretas que o ar: embora possamos experienciar este último e não duvidemos da realidade da sua existência, não o vemos (não o podemos desenhar, como alguns diriam) e por isso não é tão concreto como coisas -sereias, por exemplo- que sabemos como são, que podemos representar visualmente, quer elas existam ou não. Daí a força existencial atribuída às realidades dos universos de crença que já Lakoff apresenta 


\section{José Teixeira}

como detentores de capacidade de constituição de grupos conceptuais autónomos dentro da categorização linguística através do designado

"the myth-and-belief principle:

If some noun has characteristic $\mathrm{X}$ (on the basis of which its class membership is expected to be decided) but is, through belief or myth, conected with characteristic $\mathrm{Y}$, then generally it will belong to the class corresponding to $\mathrm{Y}$ and not that corresponding to X. (Lakoff, 1987:94)

Pode-se, assim, apresentar esta tripartição processual:

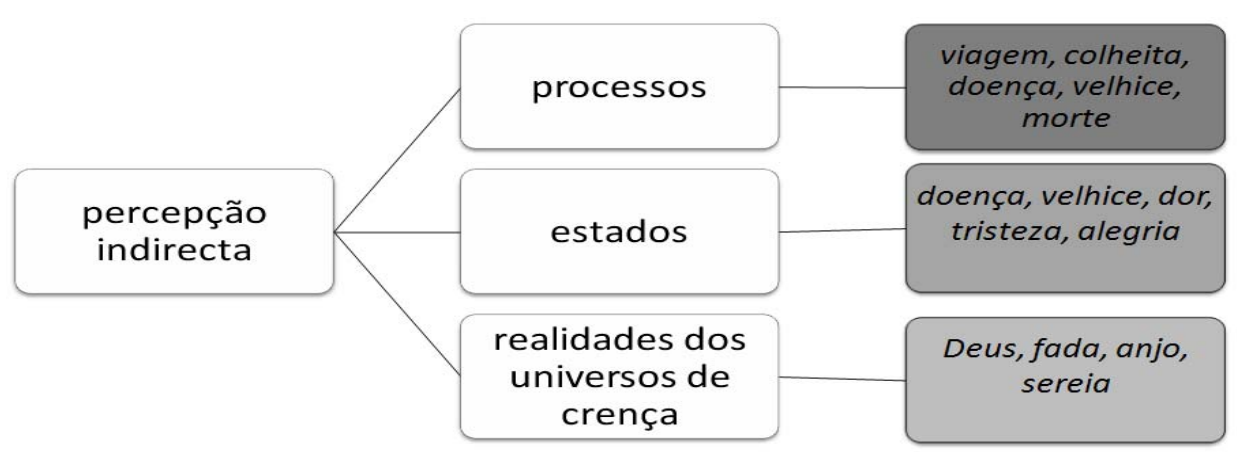

Figura 3

\subsubsection{Construções mentais complexas a partir da experienciação}

Se a percepção directa se constitui em instrumentário para a construção das imagens conceptuais construídas pela percepção indirecta (processos, estados e universos de crença), o conjunto das duas (percepção directa e indirecta) vai permitir elaborações mais complexas e abstractizantes. Se os conceitos de doença e velhice estão mediatamente ligados a percepções directas e indirectas, o de existência implica uma abstracção conceptual mais complexa. Estarão neste grupo todas as imagens mentais que a língua verbaliza e que traduzem conceptualizações construídas sobre percepções indirectas (processos, estados e universos de crença), como existência, liberdade, igualdade, fraternidade, decência. Repare-se que os conceitos relativos às percepções indirectas são adquiridos em fases etárias muito mais baixas do que estes últimos. Uma criança adquire primeiro os seus conceitos de doença, morte, alegria, Deus, fada do que os de igualdade (não o de igual), fraternidade ou decência. 


\subsubsection{Construções mentais complexas de experienciação impossível}

Por último, podemos elencar um conjunto de conceitos que não se podem basear nem directa nem indirectamente nas percepções experienciadas, já que estas mantêm com eles uma relação de impossibilidade existencial. Designamolos por "construções mentais complexas de experienciação impossível”, exactamente porque nas suas definições entram aspectos que contradizem a forma como pensamos a realidade e que, por isso, esses mesmos conceitos se nos afiguram contraditórios.

Sirvam de exemplos os conceitos euclideanos de ponto e linha. Ponto: algo que não tem comprimento, nem largura nem altura; linha: só tem comprimento e não tem espessura nem largura. Ora no mundo que nós vivemos, algo sem, pelo menos, duas dimensões é impossível de experienciar sensorialmente. Imaginamos tudo a duas ou três dimensões. Um ponto é sempre (imageticamente) qualquer coisa e uma linha tem de ser imaginada com uma qualquer espessura. Estes e outros conceitos técnico-científicos representarão o grau de abstracção mais elevado já que implicam abstrair da realidade aspectos sem os quais a realidade que nós conhecemos deixa de ter a possibilidade de existência real.

Estas construções mentais que agora se referem não são comparáveis com as dos universos de crença. Estas últimas, como Deus, fadas, sereias, podem não ter existência real, mas são imaginadas como essencialmente possíveis de existir. Os seus atributos assentam em aspectos da experiência: uma fada é como uma senhora que voa e tem uma varinha que faz tudo o que ela quer; uma sereia tem o tronco e a cabeça e braços de rapariga e o resto do corpo de peixe. Quando não é possível construir com peças da natureza, as realidades dos universos de crença são metaforizadas: Deus é pai, Deus é homem, Deus perdoa, Deus zanga-se, etc... ${ }^{15}$

\subsection{A realidade e a percepção}

Podemos, em jeito de síntese, apresentar em esquema a hierarquia perceptiva que subjaz à forma como progressivamente construímos conceitos complexos a abstractos a partir das nossas percepções sensoriais. Podem-se, metodologicamente, elencar nove graus:

\footnotetext{
15 Isto não quer dizer que todos os conceitos dos universos de crença sejam construídos metaforicamente. A maioria são-no, mas pode haver conceitos “incompreensíveis", por exemplo o conceito cristão da unidade-trindade de Deus: Deus é uno (uma pessoa) e trino (três pessoas) simultaneamente.
} 


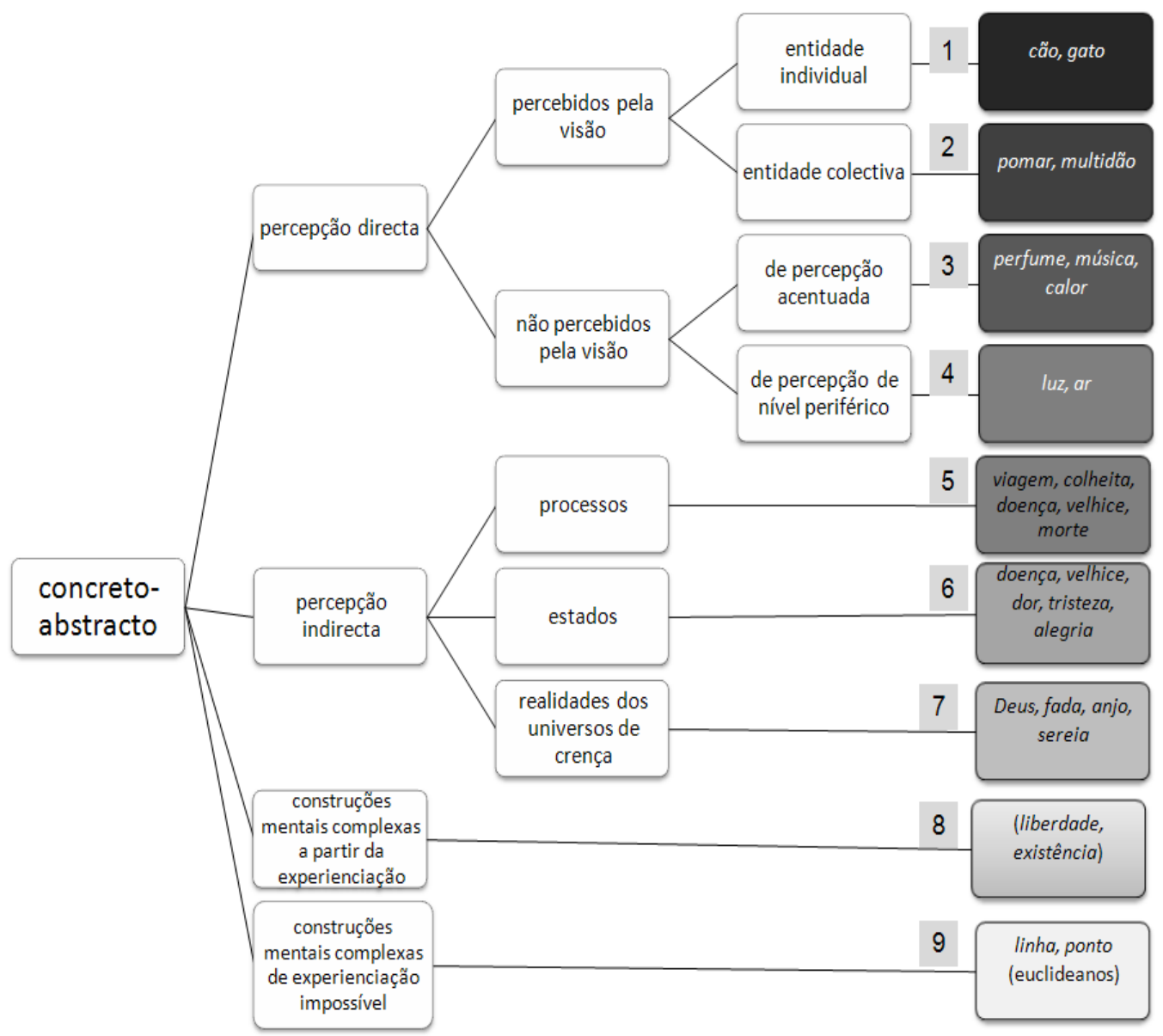

Figura 4

Se a dimensão concreto-abstracto atribuída aos nomes se baseasse nesta abstracção perceptiva, ou seja, se o apoiar-se na percepção directa fosse, para cada conceito, a razão para o seu grau de "concretude”, teríamos aqui a escala para classificar os nomes, desde os mais concretos aos mais abstractos. Assim, a percepção directa, incluindo a visão, de uma entidade individual corresponderia ao grau máximo do "concreto" e as construções mentais complexas aos graus máximos do abstracto. 


\section{José Teixeira}

É este pressuposto que está presente em muitas classificações que baseiam a dimensão do "concreto" na intensidade directa das percepções.

Mas, na verdade, as coisas são mais complexas. Esta hierarquia perceptiva não é, em si, o único critério de atribuição do grau na escala concreto-abstracto para as percepções construídas. Se o fosse, os conceitos construídos através da percepção directa (como luz, ar, calor) deveriam ser considerados como mais concretos do que aqueles em que não entra a percepção directa: os processos, os estados e os universos de crença. Mas, na realidade, não é isso que acontece: as sereias aparecem em todos os inquéritos como mais concretas do que o ar, do que a luz ou do que a velhice. Veja-se como ar, luz, dia, de percepção directa, embora de nível periférico (nível 4 no esquema proposto), foram deslocados para o abstracto (para depois dos conceitos do nível5 e de alguns do nível 6), perdendo o lugar que lhes competiria, que deveria ser antes das realidades de percepção indirecta (níveis 5, 6 e 7):

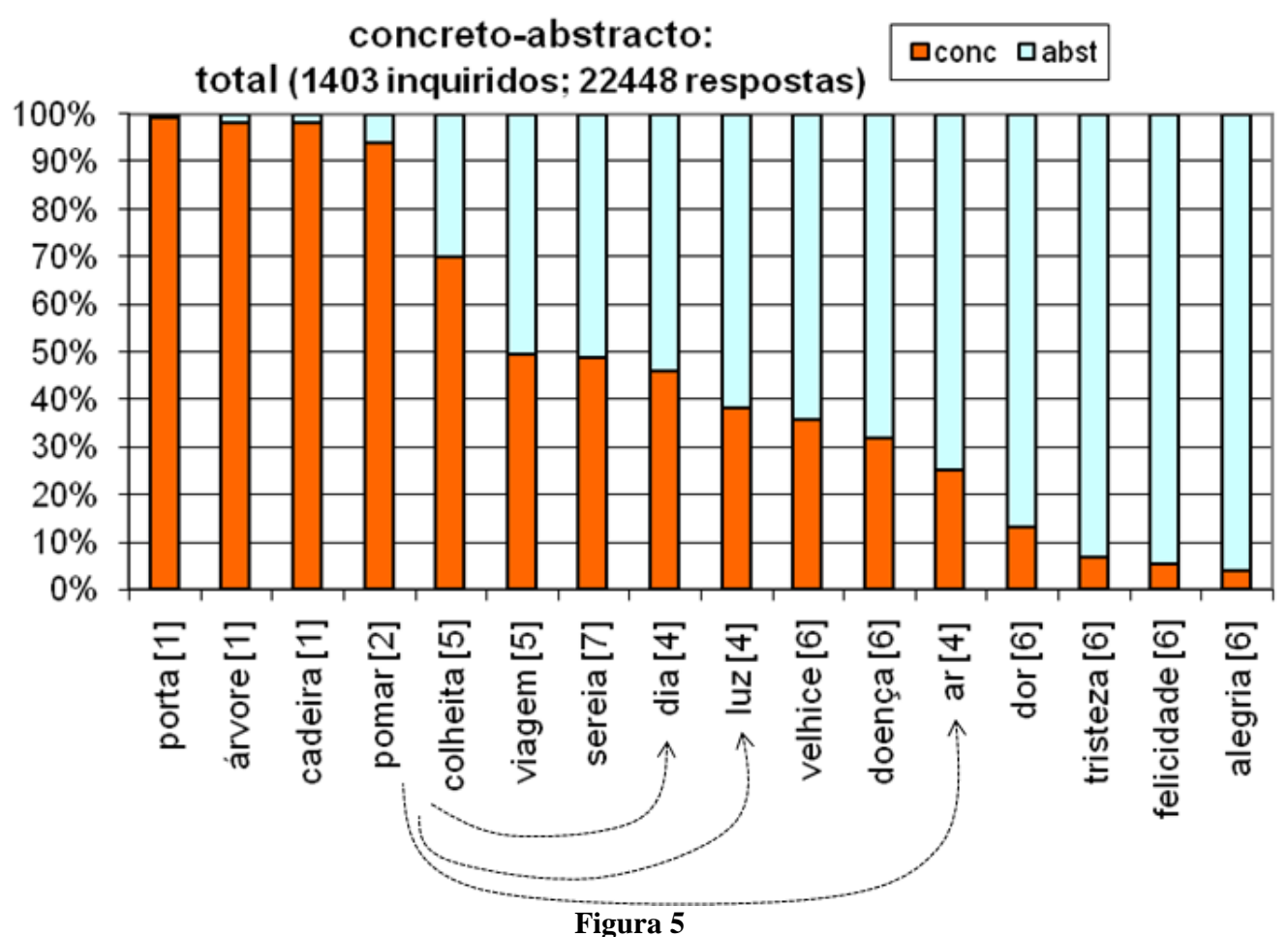

A conclusão que se evidencia destas movimentações é, obviamente, a não coincidência entre alto grau de percepção directa e alto grau de concretude. E 


\section{José Teixeira}

porquê? Simplesmente porque as várias percepções sensoriais não detêm todas o mesmo grau de importância. A visão detém um peso incomparavelmente superior aos outros sentidos. Se uma realidade física, ao ser cognitivamente assimilada, não tiver a visão como mecanismo sensorial principal é mentalmente percepcionada como de concretude menor. Assim se explica que as percepções ligadas ao calor, à luz, ao ar sejam lexicalizadas em nomes deslocados para a zona de abstracção mais do que o que faria supor o facto de serem directa e sensorialmente apreendidas.

Mas esta é apenas parte da questão. O lugar final que a conceptualização nominalizada irá ocupar na escala, para além destes factores ligados à percepção, vai depender essencialmente das características da sua construção como imagem mental. Se esta puder for visualmente representável, ela irá ser nominalizada num termo altamente dotado de concretude, independentemente da realidade (acreditada, suposta ou negada) da existência do referente. E é sobretudo esta a razão que leva a que as sereias (de grau 7 na escala proposta da percepção directa) sejam mais concretas do que o ar (de grau 4, muito mais imediatamente perceptível). Veja-se esta deslocação perceptiva no gráfico dos resultados globais (Figura 6)

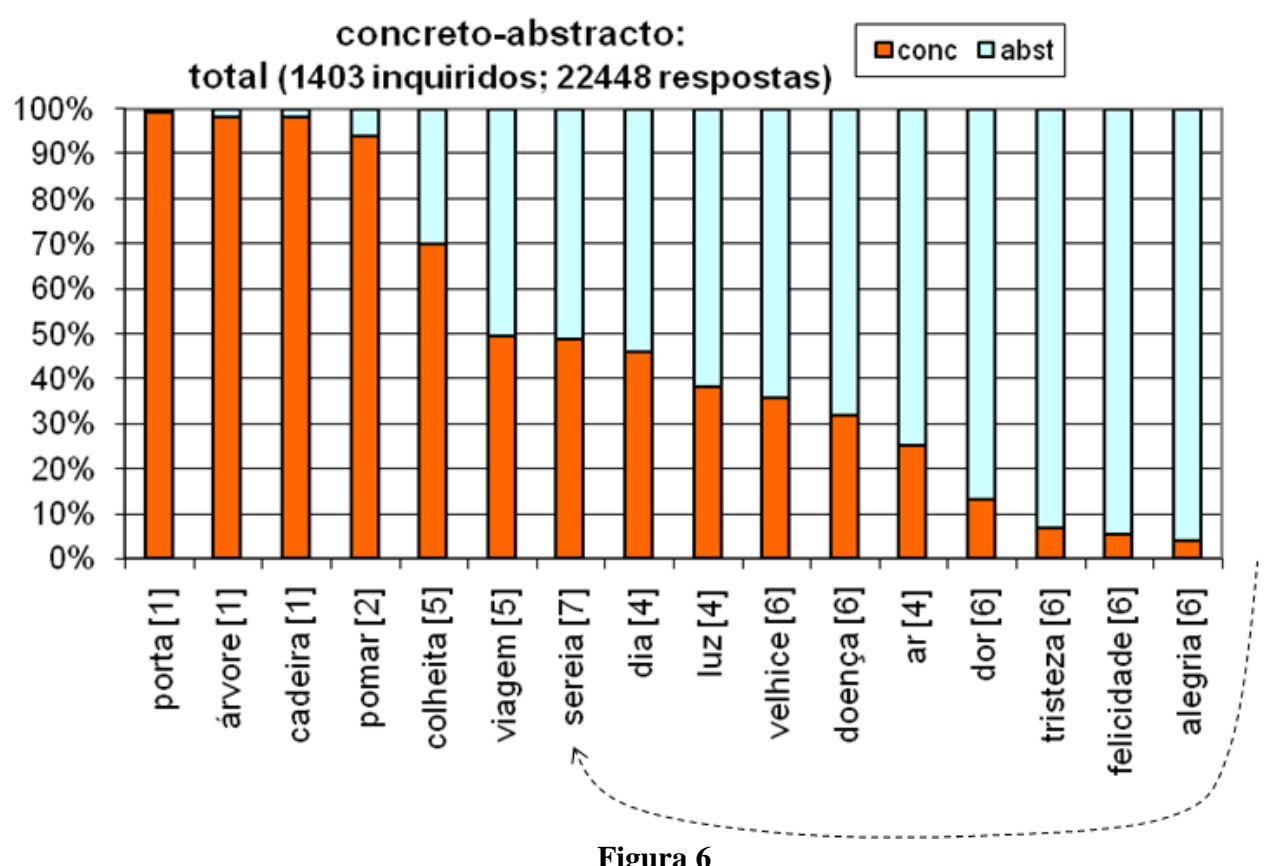

Figura 6 


\section{Que utilidade tem a oposição concreto abstracto nos nomes?}

O axioma de fundo que justifica a tradição gramatical que valoriza esta oposição é a velha dicotomia cartesiana realidade física-realidade espiritual. E porque se crê que as palavras nomeiam as duas, perfeitamente delimitáveis e distintas, a terminologia gramatical tradicional pretende, com a dualidade concreto-abstracto, retratar a referencialidade nominal.

Vista por esta perspectiva, como uma classificação dualista e opositiva, parece inquestionável que não faz grande sentido nem tem grande utilidade. Atribuir a característica de "concreto" ou "abstracto" a alguns nomes que se situam nos extremos da oposição poderá ser compreensível. No entanto, para uma grande parte do léxico, para os nomes que referem as conceptualizações elaboradas através de percepções sem a visualização ou das percepções indirectas, a dualidade "ou concreto ou abstracto" não tem grande cabimento ou justificação. Como até as análises de proveniência estruturalista e generativista concordam (agora), a oposição terá que ser entendida como escalar, gradual, sendo cada nome possuidor de um grau de concretude ou abstracção maior ou menor em função da forma como a imagem mental que ele transporta representa o modo como apreendemos a realidade.

E será nesta vertente que a oposição tem a sua utilidade. Ela demonstra como as imagens mentais que construímos sobre a realidade e que lexicalizamos estão profundamente dependentes da forma e dos mecanismos com que conhecemos, apreendemos e organizamos cognitivamente todo o processo. E que o chamado "conhecimento linguístico", independente do conhecimento total que temos sobre a realidade, é um mito. O conhecimento linguístico não é um conhecimento "ao lado" de todo o "outro", com instrumentos e mecanismos diferentes. É que qualquer conhecimento resulta de um processo complexo através do qual apreendemos (com todos os instrumentos e mecanismos cognitivos) informação que armazenamos mentalmente, armazenamento esse inseparável, para quem fala uma língua natural, dos processos que envolvem o conceptual e o linguístico.

A importância dos instrumentos de apreensão (se a visão ou outro) e o peso da representatividade visualizável (sereias imageticamente como "mais concretas" que o ar) demonstram a realidade da corporização do significado e como esta privilegia alguns critérios e instrumentos cognitivos sobre outros.

E se a vertente sensitiva é importante, se a fisicidade sentida é vertente que a lexicalização não descura, a relativa indiferença à existência real ou não das entidades dos universos de crença mostra até que ponto as nossas construções mentais são complexas. Partimos sempre da realidade sentida, percepcionada: mas 


\section{José Teixeira}

depois construímos imagens mentais cada vez mais complexas, mais abstractas, que envolvem processos, estados, construções mentais que nunca experienciámos directamente (deus, sereias, fadas) e mesmo construções mentais tão complexas que sabemos serem impossíveis de experienciar, como a imagem de algo que não tem comprimento, nem largura nem altura. Mas é esta mesma a essência nominativa da língua: não nomear as coisas da "realidade existente", mas construir uma realidade que tem que resultar necessariamente da forma como apreendemos o que consideramos existir.

\section{Referências bibliográficas}

Damásio, António, 1995, O Erro de Descartes, Europa-América.

Damásio, António, 1999 (2004), O Sentimento de Si: O Corpo, a Emoção e a Neurobiologia da Consciência, Publicações Europa-América.

Lakoff, George, 1987, Women, Fire, and Dangerous Things: What Categories Reveal about the Mind, The University of Chicago Press, Chicago and London.

Lakoff, George, 1995, "Embodied Minds and Meanings", in BAUMGARTNER, Peter e PAYR, Sabine (Edit.), Speaking Minds - Interviws with Twenty Eminent Cognitive Scientists, Princeton University Press.

Teixeira, José, 2001, A Verbalização do Espaço: modelos mentais de frente/trás, Universidade do Minho/Centro de Estudos Humanísticos, Braga.

\section{Gramáticas e manuais referidos}

Borregana, António Afonso, 1998, Gramática Universal - Língua

Portuguesa,,Texto Editora, p.118

Duarte, Inês, Terminologia Linguística para os Ensinos Básico e Secundário, , 1.1. versão em CD-ROM.

Mateus, Ma Helena, 2003:, Gramática da Língua Portuguesa, Almedina, p. 211.

Miguel, Jorge, "Estudos de Língua Portuguesa", Editora Harbra, São Paulo, 1989, p. 67

Pinto, José Manuel de Castro, Lopes, Maria do Céu Vieira, Gramática do Português Moderno, (Ensino Básico e Secundário), Plátano Editora, Setembro 2002, p. 115

S/ Autor, Despertar - Gramática $3^{\circ}$ e $4^{\circ}$ anos, Hortência Neto, 2004, p.86

Silva, Ana Maria, Fontes, Maria José, Castro, Rogério de, Palavras em Português (Língua Portuguesa $7^{\circ}$ ano), Porto Editora, Porto 2002, p. 102 
ANEXOS

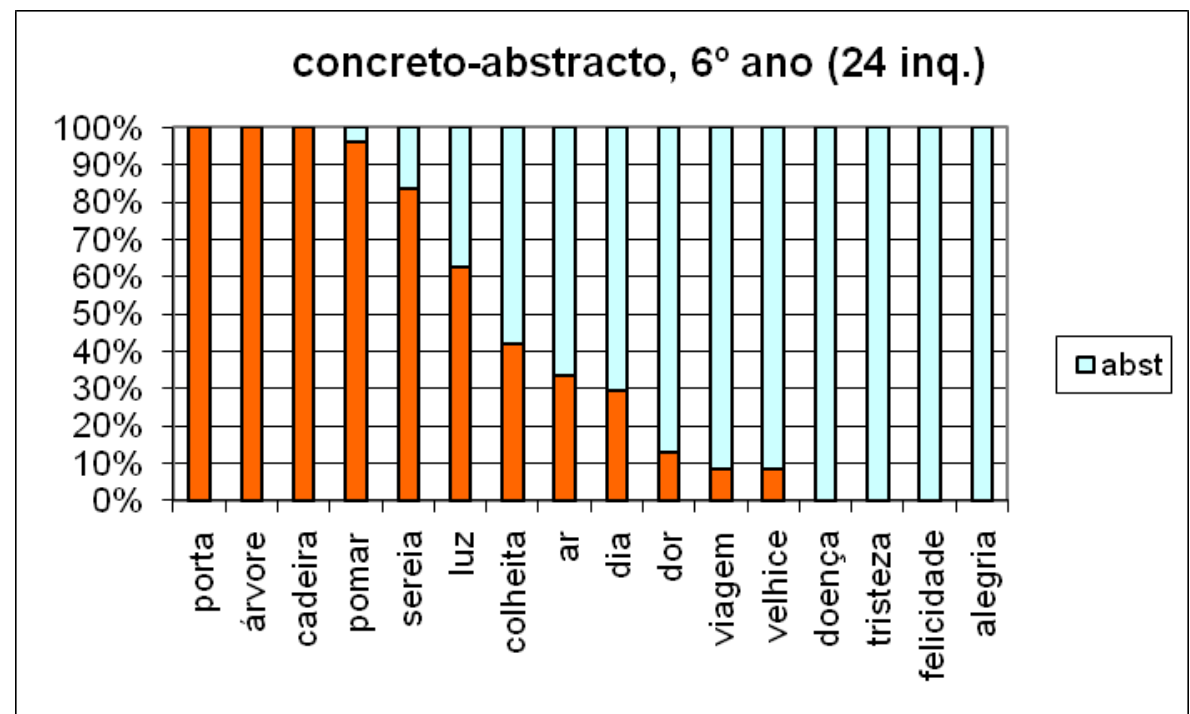

Figura 7: resultados da faixa etária 11-12 anos

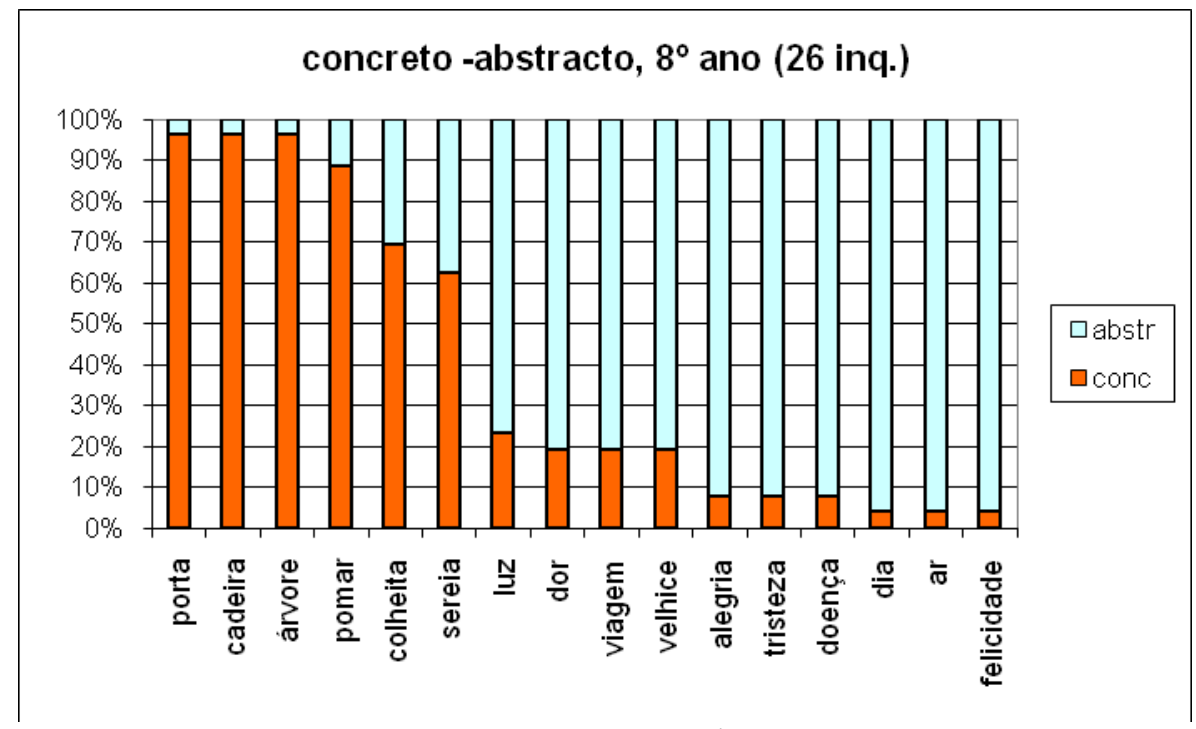

Figura 8: resultados da faixa etária 13-14 anos 
José Teixeira

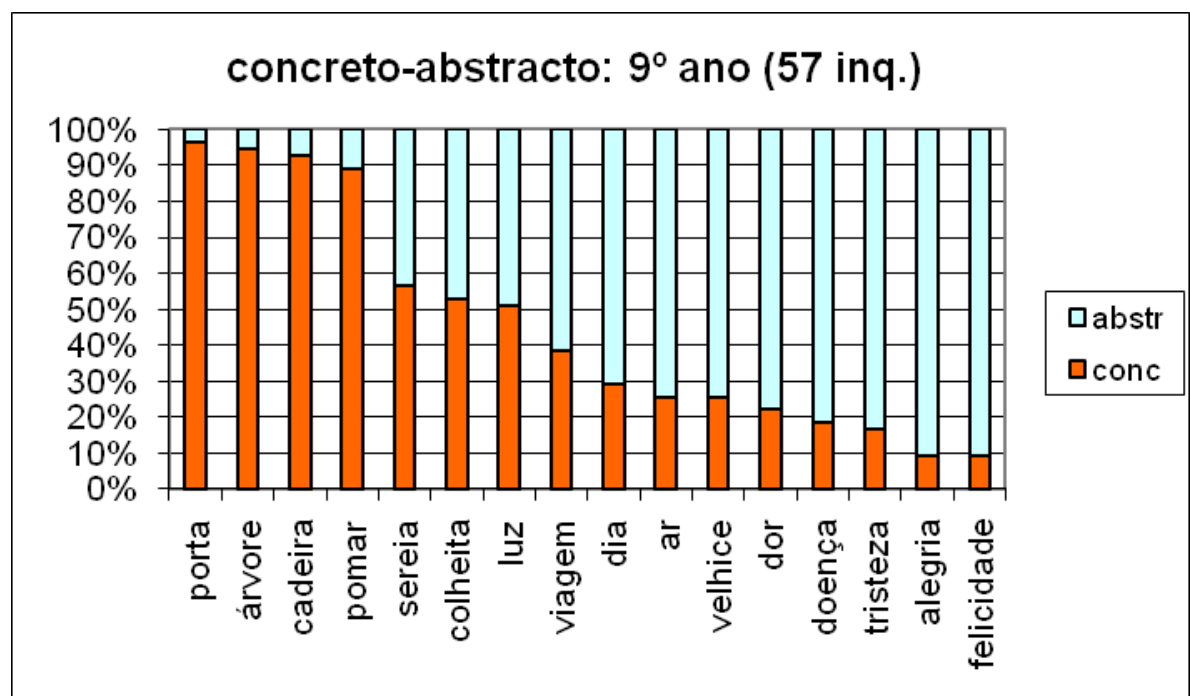

Figura 9: Resultados da faixa etária 14-15 anos

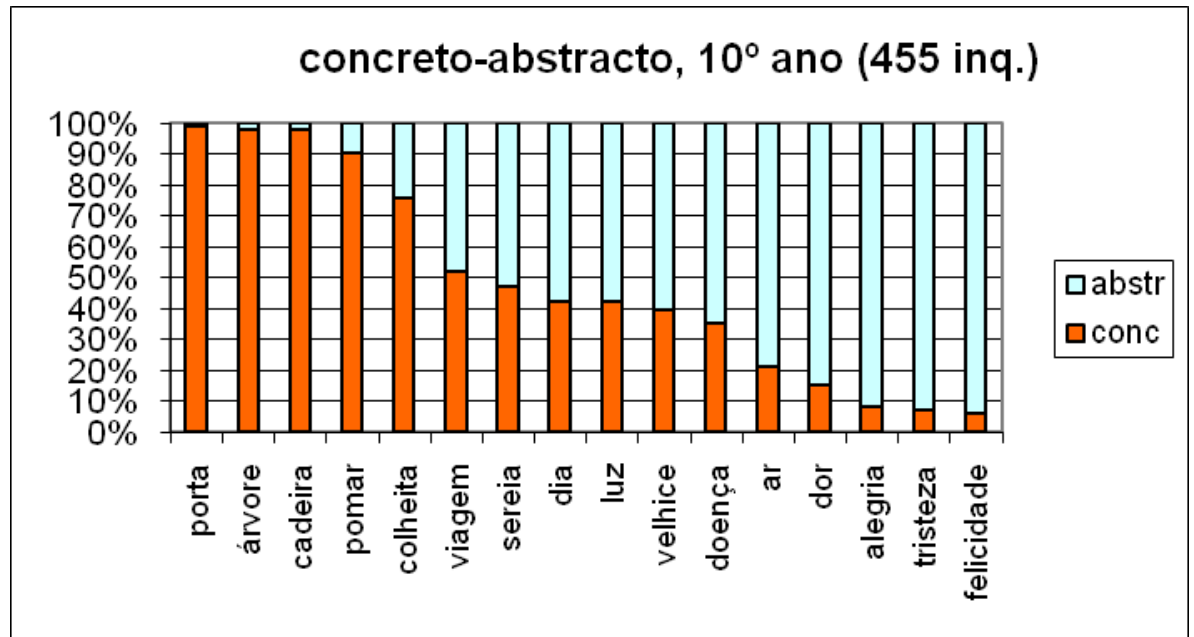

Figura 10: Resultados da faixa etária 15-16 anos 


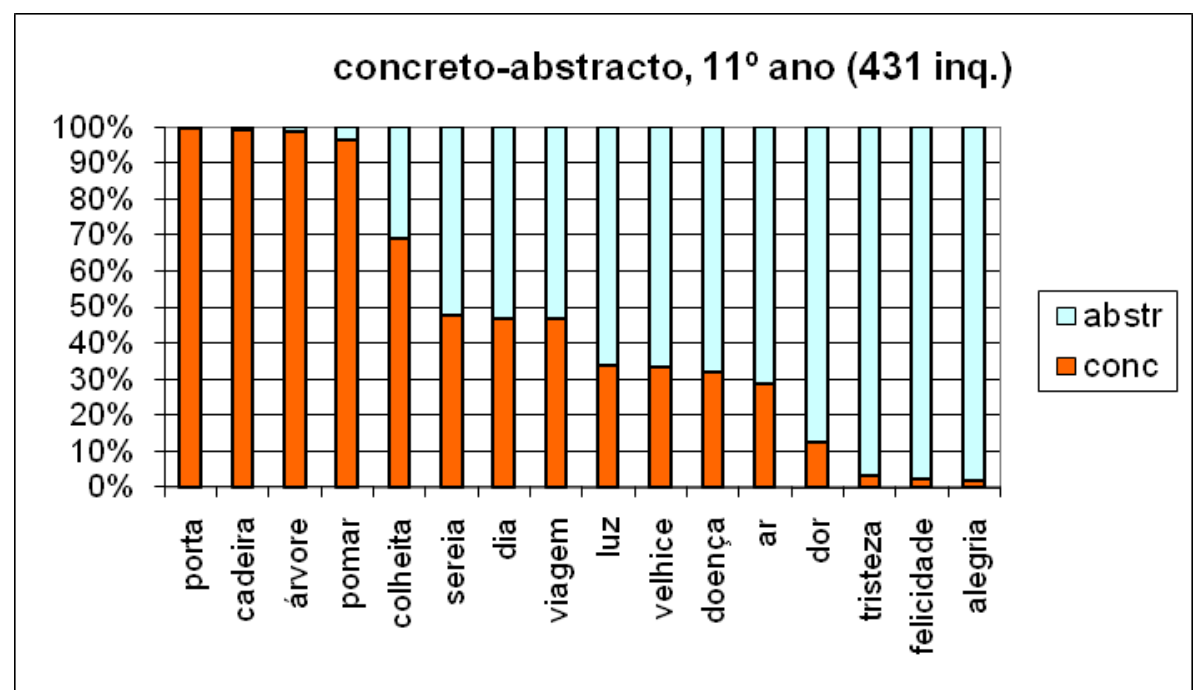

Figura 11: Resultados da faixa etária 16-17 anos

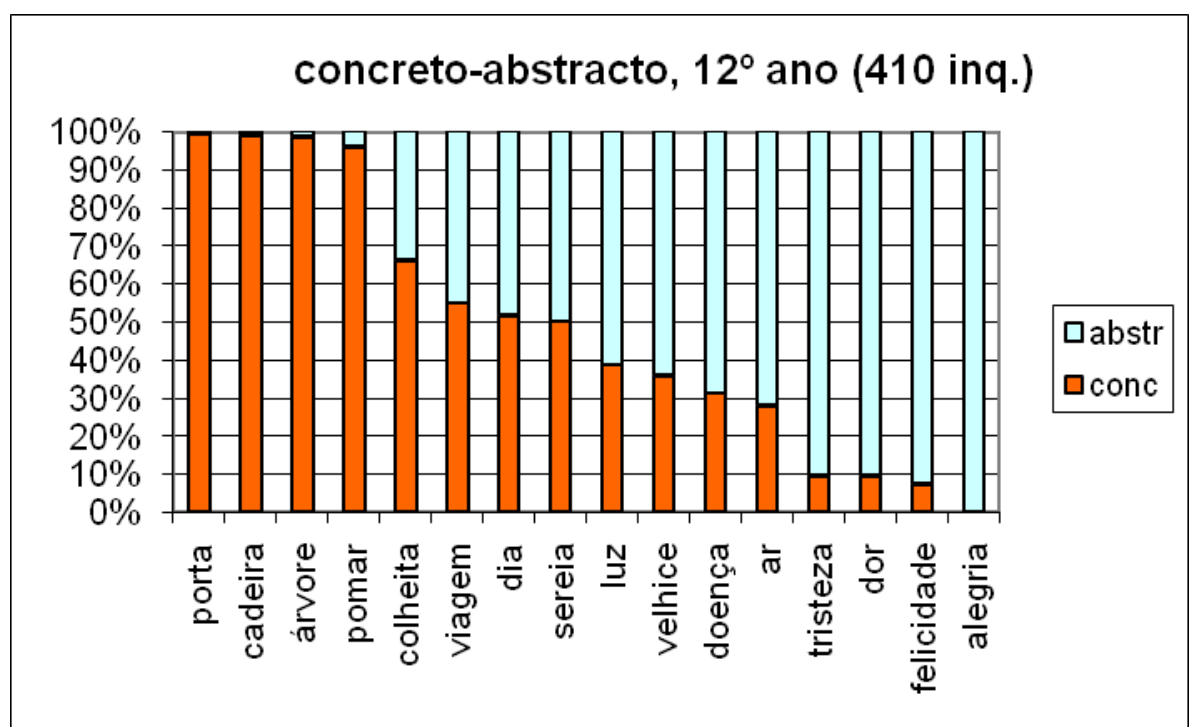

Figura 12: Resultados da faixa etária 17-18 anos 


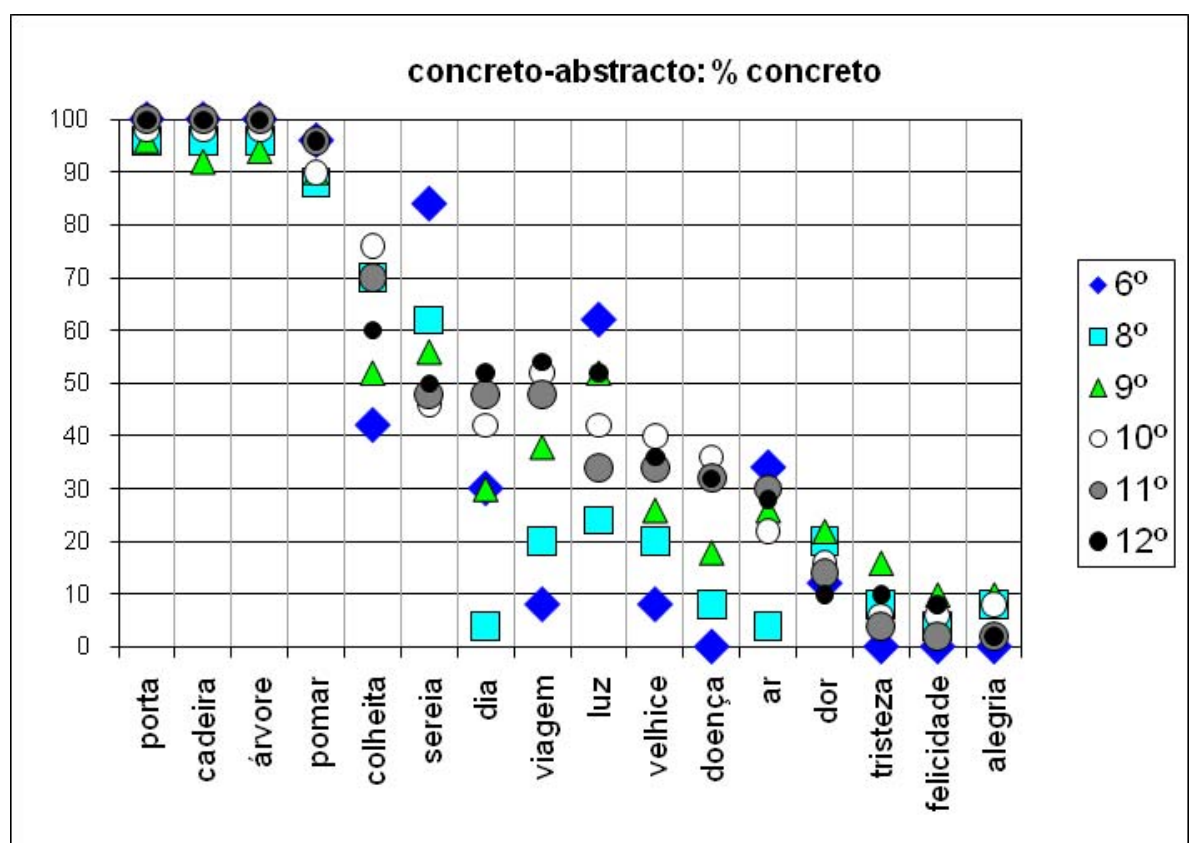

Figura 13: Comparação entre as faixas etárias/anos de escolaridade

Ano de escolaridade

\begin{tabular}{|l|l|l|}
\hline & Concreto & Abstracto \\
\hline Porta & & \\
\hline Alegria & & \\
\hline Dia & & \\
\hline Tristeza & & \\
\hline Cadeira & & \\
\hline Dor & & \\
\hline Colheita & & \\
\hline Viagem & & \\
\hline Sereia & & \\
\hline Luz & & \\
\hline Árvore & & \\
\hline Ar & & \\
\hline Velhice & & \\
\hline Pomar & & \\
\hline Felicidade & & \\
\hline Doença & & \\
\hline
\end{tabular}

Figura 14: Inquérito respondido

Revista Galega de Filoloxía, ISSN 1576-2661, 2010, 11: pp.123-149 